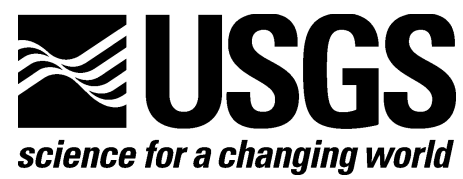

\title{
Radiocarbon Dates from Volcanic Deposits of the Chaos Crags and Cinder Cone Eruptive Sequences and Other Deposits, Lassen Volcanic National Park and Vicinity, California
}

By Michael A. Clynne, Robert L. Christiansen, Deborah A. Trimble, and John P. McGeehin

Open-File Report 02-290

U.S. Department of the Interior

U.S. Geological Survey 


\title{
U.S. Department of the Interior GALE NORTON, Secretary
}

\section{U.S. Geological Survey Charles G. Groat, Director}

\author{
U.S. Geological Survey, Reston, Virginia 2008
}

For product and ordering information:

World Wide Web: http://www.usgs.gov/pubprod

Telephone: 1-888-ASK-USGS

For more information on the USGS-the Federal source for science about the Earth, its natural and living resources, natural hazards, and the environment:

World Wide Web: http://www.usgs.gov

Telephone: 1-888-ASK-USGS

\footnotetext{
Suggested citation:

Clynne, M.A., Christiansen, R.L., Trimble. D.A., and Mc Geehin, J.P., 2008, Ra dioc arbon dates from volcanic deposits of the Chaos Crags and Cinder Cone eruptive sequences and other deposits, Lassen Volcanic National Park and vicinity, California: U.S. Geological Survey Open-file Report 02-290, 18 p. [http://pubs.usgs.gov/of/2002/of02-290/].
}

Any use of trade, product, or firm names is for descriptive purposes only and does not imply endorsement by the U.S. Government.

Although this report is in the public domain, permission must be secured from the individual copyright owners to reproduce any copyrighted material contained within this report. 


\section{Contents}

Anstract

\section{Tables}

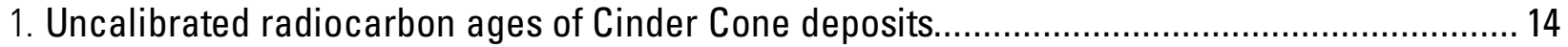

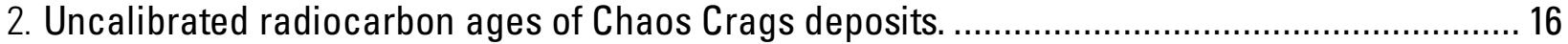

3. Stratigraphy of Chaos Crags after Muffler and others (1989) and Christiansen and others (2002) with average uncalibrated radiocarbon ages.

\section{Conversion Factors}

\section{SI to Inch/Pound}

\begin{tabular}{lcl}
\hline Multiply & By & To obtain \\
\hline Length & & \\
\hline centimeter (cm) & 0.3937 & inch (in.) \\
millimeter (mm) & 0.03937 & inch (in.) \\
meter (m) & 3.281 & foot (ft) \\
kilometer (km) & 0.6214 & mile (mi) \\
& & \\
Vertical coordinate information is referenced to the North American Vertical Datum of 1929 (NGVD 29). \\
Horizontal coordinate information is referenced to the North American Datum of 1927 (NAD 27). \\
Altitude, as used in this report, refers to distance above the vertical datum.
\end{tabular}




\title{
Radiocarbon Dates from Volcanic Deposits of the Chaos Crags and Cinder Cone Eruptive Sequences and Other Deposits, Lassen Volcanic National Park and Vicinity, California
}

\author{
By Michael A. Clynne, Robert L. Christiansen, Deborah A. Trimble, and John P. McGeehin
}

\begin{abstract}
This contribution reports radiocarbon ages obtained from charcoal, wood and other samples collected between 1979 and 2001 in Lassen Volcanic National Park and vicinity and a few samples from other nearby localities. Most of the samples are from the Chaos Crags and Cinder Cone eruptive sequences. Brief summaries are given of the Chaos Crags and Cinder Cone eruptive sequences.
\end{abstract}

\section{Analytical Procedures}

Samples with the prefix USGS to the lab number were analyzed in the Menlo Park Radiocarbon Laboratory. Samples with the prefix WW were processed in the Reston ${ }^{14} \mathrm{C}$ AMS preparatory laboratory and analyzed at the Center for Accelerator Mass Spectrometry (CAMS) at Lawrence Livermore National Laboratory. A field number is also given for each sample. The authors collected all samples unless otherwise noted in the sample description.

Any sample preparation prior to submittal to the laboratory is noted in the sample description. Unless otherwise specified, all USGS prefix samples were pretreated with an acidalkali-acid (AAA) leaching process to remove contaminant carbon in the form of inorganic carbonates and organic soil acids. Samples were converted to $\mathrm{CO}_{2}$ by combustion, stored for at least 6 weeks to allow for decay of radon and counted in low-background, anti-coincidence gasproportional counters for at least 2,400 minutes. Additional details of the pretreatment and analytical process can be found in Robinson (1977) and Robinson and Trimble (1981). WW prefix samples were pretreated with an AAA pretreatment before conversion to $\mathrm{CO}_{2}$ and reduction with $\mathrm{H}_{2}$ to pure carbon in the form of graphite over an iron catalyst. Additional details of the sample handling and analytical process can be found in McGeehin and others (2001) and Roberts and others (1997) respectively.

Ages published herein are reported as received from the analytical laboratories. No calibration to the absolute radiocarbon time scale has been performed. All ages are calculated using the Libby 5,568-year half-life for ${ }^{14} \mathrm{C}$ and with $\delta{ }^{13} \mathrm{C}=-27$ unless otherwise noted, and are given in years BP (before present, defined as 1950). Errors as stated include one standard deviation of counting statistics and an additional uncertainty attributable to isotope fractionation, counter variables and sample processing. Ages for these samples published in other venues may vary slightly as a function of calibration to the absolute time scale or by calculation of weighted averages for multiple analyses. 


\section{Sample Descriptions}

\section{Cinder Cone}

Laboratory number

USGS 2493
Field number

LC86-927 age (yrs B.P.)

$250 \pm 35$

Wood collected from standing snag in the Cinder Cone ash field, approximately $1.4 \mathrm{~km}$ south of Cinder Cone (Prospect Peak 7-1/2' quadrangle, 40 $32.12^{\prime} 121^{\circ} 19.48^{\prime}$ ). Sample consists of wood from the outermost preserved 10 rings of tree eroded by windblown ash. The snag is approximately $2 \mathrm{~m}$ from edge of the Painted Dunes lava flow, rooted in till underlying the Cinder Cone ash deposit, and was probably killed by the eruption. Sample cleaned of a small amount of lichen, and weathered surface removed by hand. Sample approximately dates the Cinder Cone eruption.
USGS 2613
LC87-1146
$440 \pm 46$
Wood collected from standing snag partially buried by lava along the eastern margin of the Fantastic Lava Beds flow, approximately $2.0 \mathrm{~km}$ east of Cinder Cone (Prospect Peak 7-1/2' quadrangle, $40^{\circ} 32.65^{\prime} 121^{\circ} 17.77^{\prime}$ ). Sample consists of wood from the outermost preserved 10 rings of tree without bark. The snag is leaning and is rooted in till underlying the Cinder Cone ash deposit and surrounded by blocks from the lava. An unknown amount of wood has been lost from the tree trunk by erosion. Sample cleaned of a small amount of lichen, and weathered surface removed by hand. Sample provides a maximum age for the Cinder Cone eruption, as the tree appears to have been significantly eroded or may have been already dead at the time of the eruption.

\section{USGS 2615 \\ LC88-1273A \\ $265 \pm 63$}

Sample collected from forest duff beneath the Cinder Cone ash deposit approximately 2.3 $\mathrm{km}$ southwest of Cinder Cone (Prospect Peak 7-1/2' quadrangle, 40 32.17' $121^{\circ} 20.52^{\prime}$ ). Sample overlies soil developed on Chaos Crags ash, and underlies the Cinder Cone ash deposit. Sample consists of charred platelets of Jeffrey Pine bark. Modern rootlets picked and sample cleaned of extraneous soil material by hand. Sample provides a direct date for the Cinder Cone eruption.
USGS 2663
LC87-1158
$430 \pm 50$

Sample collected from stump partially buried by lava along the eastern margin of the Fantastic Lava Beds flow, approximately $2.0 \mathrm{~km}$ east of Cinder Cone (Prospect Peak 7-1/2' quadrangle, $\left.40^{\circ} 32.63^{\prime} 121^{\circ} 17.80^{\prime}\right)$. Sample consists of charcoal collected from the outermost preserved 10 rings of the partially burned stump which lacks bark. The stump is rooted in till underlying the Cinder Cone ash deposit and surrounded by blocks from the lava. The tree was cut down sometime after the eruption, perhaps for tree-ring studies (Diller, 1891; Finch, 1937). An unknown amount of wood has been lost from the tree trunk by erosion. Sample provides a maximum age, as the stump appears to have been significantly eroded or may have been already dead at the time of the eruption. 
Sample collected from snag lying on the lava along the western margin of the Painted Dunes lava flow approximately $1.2 \mathrm{~km}$ southwest of Cinder Cone (Prospect Peak 7-1/2' quadrangle, $40^{\circ} 32.26^{\prime} 121^{\circ} 19.57^{\prime}$ ). Sample consists of charcoal collected from the outermost preserved 10 rings of tree without bark. The snag is charred on the side facing the lava flow. The stump of this tree is buried beneath either the ash or the lava. An unknown amount of wood has been lost from the tree trunk by burning and erosion. Sample provides a maximum age, as the tree appears to have been significantly eroded or may have been already dead at the time of the eruption.

\section{USGS 2665 \\ LC87-1174 \\ $200 \pm 50$}

Sample collected from standing snag partially buried by Cinder Cone lava flow, approximately $0.1 \mathrm{~km}$ north of intersection of the lava flow with the northeast corner of the shoreline of Snag Lake (Prospect Peak 7-1/2' quadrangle, 40 $31.44^{\prime} 121^{\circ} 18.28^{\prime}$ ). Sample consists of wood collected from the outermost preserved 10 rings of tree without bark. The snag is rooted in till underlying the Cinder Cone ash deposit and is surrounded by blocks of lava from the flow front. Sample cleaned of a small amount of lichen, and weathered surface removed by hand. Sample provides a minimum age, as the tree may not have been killed in the eruption, but nevertheless approaches the age of the Cinder Cone eruption.
USGS 2769
LC89-1480
$140 \pm 42$

Sample collected from stump of tree in the Cinder Cone ash field, approximately $2.1 \mathrm{~km}$ southwest of Cinder Cone (Prospect Peak 7-1/2' quadrangle, $40^{\circ} 31.9^{\prime} 121^{\circ} 20.2^{\prime}$ ). Sample consists of wood collected from the outermost preserved 10 rings of tree without bark. The snag is rooted in soil beneath Cinder Cone ash on the underlying andesite of Fairfield Peak. Sample cleaned of weathered surface by hand. Sample provides a minimum age, as the tree was probably not killed by the Cinder Cone eruption and continued to grow for at least several decades.
USGS 3080
LC91-1615
$200 \pm 50$

Sample collected from submerged log near northwest shore of Snag Lake (Prospect Peak $7-1 / 2^{\prime}$ quadrangle, $\left.40^{\circ} 31.3^{\prime} 121^{\circ} 18.7^{\prime}\right)$. Eruption of the Painted Dunes lava flow from Cinder Cone created Snag Lake by damming the Grassy Creek drainage from the Central Plateau of Lassen Volcanic National Park. In the late 1980s, the level of Snag Lake was lowered by drought, and many logs were exposed on the lake bed. Sample consists of wood from the outermost available portion of a log and was collected by Chris Williams, National Park Service (different log than sample USGS 3641). The log was partially decomposed and did not have any intact bark. This sample had thin, closely spaced rings and was probably a small tree. Algae were removed by scraping the outer surface of the sample. The analytical result and relationship of this sample to the lake suggest that it might directly date the eruption of Cinder Cone. However, the date could be either a minimum or maximum age depending on how quickly the tree was drowned by the rising lake, whether it was already dead, or whether it was killed by some unrelated event and fell into the lake. See USGS 3641 from the same locality. 
Sample collected from submerged log near northwest shore of Snag Lake (Prospect Peak $7-1 / 2^{\prime}$ quadrangle, $\left.40^{\circ} 31.3^{\prime} 121^{\circ} 18.7^{\prime}\right)$. Eruption of the Painted Dunes lava flow from Cinder Cone created Snag Lake by damming the Grassy Creek drainage from the Central Plateau of Lassen Volcanic National Park. In the late 1980s, the level of Snag Lake was lowered by drought, and many logs were exposed on the lake bed. Sample consists of wood from the outermost available portion of a log and was collected by Chris Williams, National Park Service (different log than sample USGS 3080). The log was partially decomposed and did not have any intact bark. Algae were removed by scraping the outer surface of the sample. The analytical result and relationship of this sample to the lake suggest that it might directly date the eruption of Cinder Cone. However, the date could be either a minimum or maximum age depending on how quickly the tree was drowned by the rising lake, whether it was already dead, or whether it was killed by some unrelated event and fell into the lake. See USGS 3080 from the same locality.

\section{USGS 3683 \\ LC95-2139A \\ $270 \pm 42$}

Sample collected from forest duff beneath the Cinder Cone ash approximately $1.4 \mathrm{~km}$ north of Butte Lake Ranger Station (Prospect Peak 7-1/2' quadrangle, 40 34.75' $121^{\circ} 18.26^{\prime}$ ). Sample overlies soil developed on Chaos Crags ash and underlies Cinder Cone ash deposit (10 $\mathrm{cm}$ of unit 2 and $30 \mathrm{~cm}$ of unit 3 of Heiken (1978); unit 1 missing at this locality. Sample consists of charred platelets of Jeffrey Pine bark. Modern rootlets picked out by hand and sample cleaned of extraneous soil material by washing in water. Sample directly dates the Cinder Cone eruption.

\section{$\begin{array}{llr}\text { USGS } 3684 & \text { LC95-2144 } & 255 \pm 46\end{array}$}

Sample collected from tree almost completely buried by lava along the northwest margin of the Fantastic Lava Beds lava flow from Cinder Cone (Prospect Peak 7-1/2' quadrangle, $40^{\circ}$ $\left.33.24^{\prime} 121^{\circ} 18.59^{\prime}\right)$. Sample consists of the outer 10 rings of an aspen tree that was growing along the margin of ancient Lake Bidwell (Diller, 1891). Lake Bidwell was considerably reduced in size by the Cinder Cone lava flows, and its remnant is now Butte Lake (Clynne and others, 2000). Although the tree trunk lacked bark, the sample was collected from the outer part of the tree where two branches come together and indicate that the sample was from the living surface of the tree (see illustration in Clynne and others, 2000). Sample was covered with moss, which was removed by hand. This sample is considered to be the best of the Cinder Cone samples, most accurately dating the eruption of the Cinder Cone lava flows.

\section{Chaos Crags}

Map units designated for samples from the volcanic deposits of the Chaos Crags eruptive sequence are those of Christiansen and others (2002). Unit pc as mapped by them consists of an initial fallout pumice and three pyroclastic flows here referred to by their stratigraphic relationships as the lower, middle and upper pyroclastic flow. A widespread fallout pumice deposit is also associated with the upper pyroclastic flow. 
Charcoal collected from the fall deposit related to the upper pyroclastic flow from Chaos Crags in the Devastated Area (West Prospect Peak 7-1/2' quadrangle, 40 30.75' $121^{\circ} 29.68^{\prime}$ ). The fall deposit is overlain by May 1915 deposits at this locality. Sample may have been slightly reworked by the 1915 eruption. Sample consists of a small lump of charcoal. Modern rootlets were picked out by hand. Sample dates the last major explosive phase of the Chaos Crags eruptive sequence (unit pc, Christiansen and others, 2002).

\section{$\begin{array}{lll}\text { USGS } 1353 & \text { LC81-848 } & 275 \pm 63\end{array}$}

Wood collected from one of a group of emergent and submerged trees standing in approximately $8 \mathrm{~m}$ of water near the Manzanita Creek inlet to Manzanita Lake (Manzanita Lake $7-1 / 2^{\prime}$ quadrangle, $40^{\circ} 32.08^{\prime} 121^{\circ} 33.93^{\prime}$ ). Sample consists of a single piece of wood from outer portion of a submerged but still standing tree trunk. Bark was not intact on the tree, and the trunk was overgrown by live algae. Sample collected by Gary Fry, National Park Service. Dead and live algae scraped off by hand. Sample dates death of tree by drowning when Chaos Jumbles rockfall avalanche (unit scj, Christiansen and others, 2002) dammed Manzanita Creek and formed Manzanita Lake. See USGS 1847 and 1848.

$\begin{array}{lll}\text { USGS } 1606 & \text { LC82-203 } & 1105 \pm 58\end{array}$

Charcoal collected from fall deposit related to the upper Chaos Crags pyroclastic flow in the Devastated Area (West Prospect Peak 7-1/2' quadrangle, 40 30.70' $121^{\circ} 28.73^{\prime}$ ). The deposit is overlain by May 22, 1915 pyroclastic flow at this locality. Sample may have been slightly reworked by the 1915 eruption. Sample consists of a small lump of charcoal. Modern rootlets picked out by hand. Sample dates the last major explosive phase of the Chaos Crags eruptive sequence (unit pc, Christiansen and others, 2002).

$\begin{array}{llr}\text { USGS } 1607 & \text { 82LP-16C } & 1480 \pm 58\end{array}$

Charcoal from an ash deposit underlying colluvially reworked Chaos Crags ash and pumice, approximately $2 \mathrm{~km}$ southeast of the northern end of Manzanita Lake (Manzanita Lake $7-1 / 2^{\prime}$ quadrangle, $\left.40^{\circ} 31.44^{\prime} 121^{\circ} 33.36^{\prime}\right)$. Sample consists of bits of charcoal disseminated throughout a $60-\mathrm{cm}$ thick deposit of fine yellowish ash. The deposit has a weakly developed soil and overlies till of Raker Peak (Christiansen and others, 2002). The deposit is widespread in the area around Chaos Crags and Manzanita Lake, but has been reworked by colluvial processes and originated from a volcanic eruption much older than the age of the dated sample. The location of the vent for this deposit is unknown, but likely is related to the emplacement of Lassen Peak at $27 \mathrm{ka}$. Modern rootlets picked out by hand and sample washed in water to remove adhering material. Sample provides a lower limit for the age of the Chaos Crags eruptive sequence.

\section{$\begin{array}{llr}\text { USGS 1608A } & \text { 82LP26-765A } & 1250 \pm 67\end{array}$}

Charcoal from section of Chaos Crags pyroclastic flows exposed in north wall of borrow pit at end of National Park Service road in Anklin Meadows (West Prospect Peak 7-1/2' quadrangle, $40^{\circ} 31.67^{\prime} 121^{\circ} 29.09^{\prime}$ ). Sample collected from $10 \mathrm{~cm}$ below top of uppermost Chaos Crags pyroclastic flow at this locality, directly overlain by May 19, 1915 debris flow. This pyroclastic flow contains abundant, large, conspicuously breadcrusted pumice blocks (unit pc, Christiansen and others, 2002). Sample consists of a single 10-cm piece of charcoal with 10 
thick tree rings. Modern rootlets picked out by hand. Because the position of this sample within its host tree is unconstrained, the date obtained is a maximum age for this deposit; date is 125 to 205 years older than that of a stratigraphically older sample from the same section (USGS 1609A, B). Sample puts a maximum on cessation of pyroclastic activity in the Chaos Crags eruptive sequence. See USGS 1609A, 1609B and 2343 from the same locality.

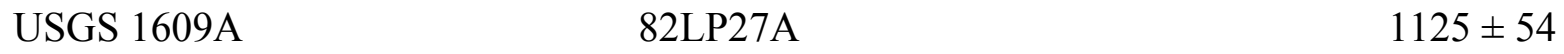

Charcoal from section of Chaos Crags pyroclastic flows exposed in north bank of borrow pit at end of NPS service road in Anklin Meadows (West Prospect Peak-7 1/2' quadrangle, 40 ${ }^{\circ}$ $31.67^{\prime} 121^{\circ} 29.09^{\prime}$ ). Sample collected from outer 10 rings just below intact bark of a 70-cmdiameter Jeffrey Pine tree trunk in the oldest of the three Chaos Crags pyroclastic flows at this locality (unit pc, Christiansen and others, 2002). Distilled sap from the sampled tree trunk penetrates into the overlying pyroclastic flow and indicates that the two flows cooled as a single unit. Modern rootlets picked out by hand. Sample dates initiation of Chaos Crags eruptive sequence and duplicates USGS 1609B. See USGS 1608A, 1609B and 2343 from the same locality.
USGS 1609B
82LP27B
$1035 \pm 54$

Charcoal from section of Chaos Crags pyroclastic flows exposed in north bank of borrow pit at end of NPS service road in Anklin Meadows (West Prospect Peak 7-1/2' quadrangle, $40^{\circ}$ $\left.31.67^{\prime} 121^{\circ} 29.09^{\prime}\right)$. Sample collected from outer 10 rings just below intact bark of a $70-\mathrm{cm}-$ diameter Jeffrey Pine tree trunk in the oldest of the three Chaos Crags pyroclastic flows at this locality (unit pc, Christiansen and others, 2002). Distilled sap from the sampled tree trunk penetrates into the overlying pyroclastic flow and indicates that the two flows cooled as a single unit. Modern rootlets picked out by hand. Sample dates initiation of Chaos Crags eruptive sequence and duplicates USGS 1609A. See USGS 1608A, 1609A, and 2343 from the same locality.

\section{USGS 1612 \\ 82LP29-330 \\ $1065 \pm 58$}

Charcoal from section of Chaos Crags pyroclastic flows exposed in the south bank of Manzanita Creek (Manzanita Lake 7-1/2' quadrangle, 40 31.82' $121^{\circ} 33.08^{\prime}$ ) near measured section 1 of Crandell and others (1974). Sample consists of disseminated bits of charcoal collected from basal $5 \mathrm{~cm}$ of the lowermost Chaos Crags pyroclastic flow at this locality (unit pc, Christiansen and others, 2002). This pyroclastic flow directly overlies till. Modern rootlets picked out by hand and sample washed in water to remove adhering material. Sample dates initiation of the Chaos Crags eruptive sequence. See samples USGS 1610 and 1611 from the same locality.
USGS 1614
82LP30A
$1175 \pm 54$

Charcoal from section of Chaos Crags pyroclastic flows exposed in the south bank of Manzanita Creek approximately 75m southeast of NPS water tank (Manzanita Lake 7-1/2' quadrangle, $40^{\circ} 31.90^{\prime} 121^{\circ} 33.15^{\prime}$ ). This locality is the same as measured section 1 of Crandell and others (1974). Sample collected from basal $10 \mathrm{~cm}$ of the lowest Chaos Crags pyroclastic flow at this locality (unit pc, Christiansen and others, 2002), which directly overlies till. Sample consists of twigs up to 1-cm diameter, probably manzanita wood. Modern rootlets picked out by 
hand and sample washed in water to remove adhering material. Sample dates initiation of Chaos Crags eruptive sequence. See USGS 1616, 2346 and 2347 from the same locality.

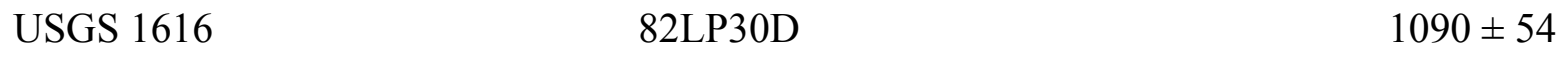

Charcoal from section of Chaos Crags pyroclastic flows exposed in the south bank of Manzanita Creek approximately $75 \mathrm{~m}$ southeast of NPS water tank (Manzanita Lake 7-1/2' quadrangle, $\left.40^{\circ} 31.98^{\prime} 121^{\circ} 33.15^{\prime}\right)$. This locality is the same as measured section 1 of Crandell and others (1974). Sample collected from basal portion of the uppermost Chaos Crags pyroclastic flow at this locality and contains abundant, large, conspicuously-breadcrusted pumice blocks (unit pc, Christiansen and others, 2002). Sample consists of small twigs from an 8-cmdiameter log with intact bark. Modern rootlets picked out by hand and sample washed in water to remove adhering material. Sample dates the last major explosive phase of the Chaos Crags eruptive sequence. See USGS 1614, 2346 and 2347 from the same locality.

$\begin{array}{llr}\text { USGS } 1847 \quad \text { LC83-396A } & 265 \pm 42\end{array}$

Wood collected from one of a group of emergent and submerged trees standing in approximately $8 \mathrm{~m}$ of water near the Manzanita Creek inlet to Manzanita Lake (Manzanita Lake $7-1 / 2^{\prime}$ quadrangle, $40^{\circ} 32.08^{\prime} 121^{\circ} 33.93^{\prime}$ ). Sample consists of the outermost 10 growth rings of the closer-to-shore of two standing Jeffrey Pine trees emergent from the lake. Bark not intact on the tree, but smooth outer surface indicates that there was probably no erosion of the tree. Small amount of algae growing on the surface was scraped off the sample by hand. Sample dates death of tree by drowning when Chaos Jumbles rockfall avalanche (unit scj, Christiansen and others, 2002) dammed Manzanita Creek and formed Manzanita Lake. See USGS-1353 and 1848.

\section{$\begin{array}{llr}\text { USGS } 1848 & \text { LC83-396B } & 305 \pm 58\end{array}$}

Wood collected from one of a group of emergent and submerged trees standing in approximately $8 \mathrm{~m}$ of water near the Manzanita Creek inlet to Manzanita Lake (Manzanita Lake $7-1 / 2^{\prime}$ quadrangle, $\left.40^{\circ} 32.08^{\prime} 121^{\circ} 33.93^{\prime}\right)$. Sample consists of the outermost 10 growth rings of the farther-from-shore of two standing Jeffrey Pine trees emergent from the lake. Bark not intact on the tree, but smooth outer surface indicates that there was probably no erosion of the tree. Small amount of algae growing on the surface was scraped off by hand. Sample dates death of tree by drowning when Chaos Jumbles rockfall avalanche (unit scj, Christiansen and others, 2002) dammed Manzanita Creek and formed Manzanita Lake. See USGS-1353 and 1847.
USGS 2047
LC84-440
$1005 \pm 58$

Charcoal from composite section of Chaos Crags pyroclastic deposits collected from hand-dug pit along Manzanita Creek west of the NPS fire road (Manzanita Lake 7-1/2' quadrangle, $40^{\circ} 30.21^{\prime} 121^{\circ} 32.20^{\prime}$ ). Sample consists of small bits of charcoal from about 50 $\mathrm{cm}$ below the top of an 80 -cm-thick ash layer directly overlying till. Sample underlies a pink layer correlated to the boundary between the middle and upper of the three Chaos Crags pyroclastic flows (unit pc, Christiansen and others, 2002), which is overlain in turn by ejecta correlated with the fall deposit associated with the upper pyroclastic flow. Modern rootlets picked out by hand and sample washed with water to remove adhering material. Sample dates initiation of the explosive phase of the Chaos Crags eruptive sequence. 
Charcoal collected from a 3-m-thick section of Chaos Crags pyroclastic flows in streambank exposure on Manzanita Creek (Manzanita Lake 7-1/2' quadrangle, 40 $30.57^{\prime} 121^{\circ} 31.81^{\prime}$ ). Sample consists of outer 5 rings collected from beneath intact bark on charcoalized log in lower of the two pyroclastic flows at this locality (the lower and middle pyroclastic flows from Chaos Crags; unit pc, Christiansen and others, 2002). Pyroclastic flows underlain by till and overlain by May 22, 1915 debris flow from Lassen Peak. Modern rootlets picked out by hand. Sample dates initiation of Chaos Crags eruptive sequence.

\section{USGS 2343 \\ LC85-711 \\ $1045 \pm 42$}

Charcoal from section of Chaos Crags pyroclastic flows exposed in north wall of borrow pit at end of NPS service road in Anklin Meadows (West Prospect Peak 7-1/2' quadrangle, $40^{\circ}$ $\left.31.67^{\prime} 121^{\circ} 29.09^{\prime}\right)$. The sample is from the youngest pyroclastic flow at this locality, contains abundant, large, conspicuously breadcrusted pumice blocks and is the upper of the three Chaos Crags pyroclastic flows (unit pc, Christiansen and others, 2002). Overlies older Chaos Crags pyroclastic flows and is overlain by May 19, 1915 debris flow. Sample collected from outer 10 rings just below intact bark of a charcoalized log. Modern rootlets picked out by hand. Sample dates the last major explosive phase of the Chaos Crags eruptive sequence. See USGS 1608A, 1609A, and 1609B from the same locality.
USGS 2344
$85 \mathrm{LP} 170$
$1015 \pm 42$

Charcoal from the fall deposit associated with the upper pyroclastic flow from Chaos Crags, approximately $0.5 \mathrm{~km}$ southeast of Old Boundary Spring (West Prospect Peak 7-1/2' quadrangle, $40^{\circ} 31.2^{\prime} 121^{\circ} 28.5^{\prime}$ ). Sample collected at base of colluvium consisting of Chaos Crags pumice exposed in pit. Sample directly overlies ash cloud deposit related to the upper Chaos Crags pyroclastic flow (unit pc, Christiansen and others, 2002). Sample consists of charcoalized twigs. Modern rootlets picked out by hand. Sample dates the last major explosive phase of the Chaos Crags eruptive sequence.

$\begin{array}{lll}\text { USGS } 2345 & \text { 85LP169A } & 1130 \pm 42\end{array}$

Charcoal collected from a section of Chaos Crags pyroclastic flows in stream- bank exposure on Lost Creek (West Prospect Peak 7-1/2' quadrangle, 40 $31.3^{\prime} 121^{\circ} 28.95^{\prime}$ ). Sample consists of outer 10 rings collected from beneath intact bark on charcoalized log in middle of three pyroclastic flows at this locality (unit pc, Christiansen and others, 2002). Chaos Crags pyroclastic flows are underlain at this locality by 8-ka debris flow deposits from Lassen Peak (unit whe, Christiansen and others, 2002) and overlain by May 1915 debris flows from Lassen Peak. Modern rootlets picked out by hand. Sample dates initiation of Chaos Crags eruptive sequence.

USGS $2346 \quad$ LC85-713 $1110 \pm 42$

Charcoal from section of Chaos Crags pyroclastic flows exposed in the south bank of Manzanita Creek (Manzanita Lake 7-1/2' quadrangle, 40 31.90' $121^{\circ} 33.15^{\prime}$ ) near measured section 1 of Crandell and others (1974) and at paleomagnetic sample site 4B097 (D.E. Champion, personal communication). Sample collected from basal part of the upper Chaos Crags pyroclastic flow, which contains abundant, large, conspicuously breadcrusted pumice blocks (unit pc, Christiansen and others, 2002). Pyroclastic flow section overlies till. Sample 
consists of outer 10 rings from a charcoalized log. Modern rootlets picked out by hand. Sample dates last major explosive phase of the Chaos Crags eruptive sequence. See USGS 1614, 1616 and 2347 from the same locality.

\section{USGS 2347 \\ LC85-712 \\ $1175 \pm 42$}

Charcoal from section of Chaos Crags pyroclastic flows exposed in the south wall of Manzanita Creek (Manzanita Lake 7-1/2' quadrangle, 40 31.90' $121^{\circ} 33.15^{\prime}$ ) near measured section 1 of Crandell and others (1974) and at paleomagnetic sample site 5B143 (D.E. Champion, personal communicationn). Sample collected from basal part of the lower Chaos Crags pyroclastic flow (unit pc, Christiansen and others, 2002). This pyroclastic flow directly overlies till. Sample consists of small charcoalized branches. Modern rootlets picked out by hand and sample cleaned of soil by washing in water. Sample dates initiation of the Chaos Crags eruptive sequence. See USGS 1614, 1616 and 2346 from the same locality.

\section{WW $3286 \quad$ LC00-2353 $1170 \pm 40$}

Charcoal from section of Chaos Crags pyroclastic flows exposed in the east bank of Manzanita Creek (Manzanita Lake 7-1/2' quadrangle, 40 $31.01^{\prime} 121^{\circ} 32.48^{\prime}$ ) approximately 1.7 $\mathrm{km}$ upstream from measured section 1 of Crandell and others (1974). Sample collected from basal zone of the middle Chaos Crags pyroclastic flow (unit pc, Christiansen and others, 2002). Sample consists of an 8-cm-long and 7.5-cm-diameter section of a charcoalized Jeffrey Pine branch with bark partially intact. Outer 15 rings peeled off and sparse modern rootlets picked out by hand. Sample dates an early phase of the Chaos Crags eruptive sequence.

\section{WW $3287 \quad$ LC00-2354 $430 \pm 30$}

Charcoal from hot dome-collapse avalanche deposit approximately $1.0 \mathrm{~km}$ ESE of the location of measured section 1 of Crandell and others (1974), (Manzanita Lake 7-1/2' quadrangle, $\left.40^{\circ} 31.63^{\prime} 121^{\circ} 32.35^{\prime}\right)$. Sample collected within the basal zone of the thin edge of the dome-collapse avalanche deposit where it overlies the upper Chaos Crags pyroclastic flow, which in turn overlies till of Anklin Meadows at this locality. This deposit is interpreted as the edge of the hot dome-collapse avalanche from dome D of Chaos Crags by Christiansen and others (2002, unit scd). Sample consists of bits of thoroughly charred wood and twigs. Modern rootlets picked out by hand and sample washed in water to remove adhering soil. The paleomagnetic direction of prismatically jointed juvenile blocks in this deposit agrees with that of the older Chaos Crags pyroclastic flows and domes (D.E. Champion, in preparation). Thus, the significance of this radiocarbon age is unclear.

\section{$\begin{array}{lll}\text { WW } 3547 & \text { LC01-2365C } & 710 \pm 40\end{array}$}

Charcoal from hot dome-collapse avalanche deposit along the edge of the southernmost Sunflower Flat dome, approximately $0.8 \mathrm{~km}$ west of Hot Rock on Hwy 89 (West Prospect Peak $7-1 / 2^{\prime}$ quadrangle, $\left.40^{\circ} 32.12^{\prime} 121^{\circ} 29.95^{\prime}\right)$. Sample collected within the basal zone of the thin edge (about $15 \mathrm{~cm}$ thick) of the dome-collapse avalanche deposit where it overlies the upper Chaos Crags pyroclastic flow. This deposit is interpreted as the hot dome-collapse avalanche from dome east of Chaos Crags by Christiansen and others (2002, unit sce). Sample consists of outer parts of a thoroughly charred small branch. Modern rootlets picked out by hand. The paleomagnetic direction of prismatically jointed juvenile blocks in this deposit agrees with that 
of the older Chaos Crags pyroclastic flows and domes (D.E. Champion, in preparation). Thus, the significance of this radiocarbon age is unclear. See WW 3849 from the same deposit.

WW 3849

LC01-2368

$230 \pm 40$

Charcoal from hot dome-collapse avalanche deposit along the edge of the southernmost Sunflower Flat dome, approximately $1.1 \mathrm{~km}$ west of Hot Rock on Hwy 89 (West Prospect Peak $7-1 / 2^{\prime}$ quadrangle, $40^{\circ} 32.10^{\prime} 121^{\circ} 30.09^{\prime}$ ). Sample collected within the thin edge (about $5 \mathrm{~cm}$ thick) of the dome-collapse avalanche deposit where it overlies the upper Chaos Crags pyroclastic flow at this locality. This deposit is interpreted as the hot dome-collapse avalanche from dome east of Chaos Crags by Christiansen and others (2002, unit sce). Sample consists of bits of throughly charred wood and twigs. Modern rootlets picked out by hand and sample washed in water to remove adhering material. The paleomagnetic direction of prismatically jointed juvenile blocks in this deposit agrees with that of the older Chaos Crags pyroclastic flows and domes (D.E. Champion, in preparation). Thus, the significance of this radiocarbon age is unclear. See WW 3547 from the same deposit.

\section{Other Deposits}

Laboratory number

Field number

USGS $830 \quad$ LM79-371

age (yrs B.P.)

Sample collected from landslide in the canyon of Mill Creek (Lassen Peak 7-1/2' quadrangle, $40^{\circ} 24.82^{\prime} 121^{\circ} 30.90^{\prime}$ ). Sample collected from trunk of Noble Fir at approximately $5200^{\prime}$ elevation which is significantly below its normal growth range. The tree trunk was transported by a landslide first recognized by Crandell and Mullineaux (1970) that headed on Brokeoff Mountain and flowed about $5 \mathrm{~km}$ downstream to its present location in Mill Creek. Sample collected by M.A. Clynne and L.J.P. Muffler. Sample consists of wood collected from just below intact bark. Modern rootlets picked out by hand. Sample dates the youngest large landslide in the drainage of Mill Creek and places a constraint on the frequency of large landslides in the hyrothermally altered core of Brokeoff Volcano.

\section{USGS 1352 \\ LC81-730 \\ $7,550 \pm 58$}

Sample collected from canyon exposure in upper Lost Creek, Devastated Area, Lassen Peak (West Prospect Peak 7-1/2' quadrangle, 40 30.05' 121 $28.86^{\prime}$ ). Sample consists of thin orange-colored soil developed on debris flows comprised primarily of pinkish dacite of Lassen Peak (unit whe, Christiansen and others, 2002). Sampled unit overlies dome-collapse pyroclastic flow from Lassen Peak dated at $27.1 \mathrm{ka}$ by ${ }^{40} \mathrm{Ar} /{ }^{39} \mathrm{Ar}$ (Turrin and others, 1998). Sampled unit directly underlies deposits of the 1915 eruption of Lassen Peak. Modern rootlets picked out by hand. Sample provides a minimum age for the debris flows from Lassen Peak that are related to deglaciation after the early Holocene glacial advance on Lassen Peak (Turrin and others, 1998). See USGS 2180. 
Samples from a section of intercalated peat and ash in the western creek bank exposed just below the Highway 89 bridge over Lost Creek near Anklin Meadows (West Prospect Peak $7-1 / 2^{\prime}$ quadrangle, $40^{\circ} 32.44^{\prime} 121^{\circ} 29.52^{\prime}$ ). Final two digits in sample number indicate height in $\mathrm{cm}$ above the exposed base of section. Samples from unit 2 of measured section 2 reported by Crandell and others (1974). The part of the section from the base to 82LP28-40 consists of fluvial sand and gravel. Sample 82LP28-40 was a piece of wood. All other samples consist of peat that was thinly sliced to minimize the time span of formation. Modern rootlets picked out of all samples by hand, and wood sample washed in water to remove adhering peat. Intervals between 82LP28-42 and 82LP28-51, 82LP28-59 and 82LP28-63, and 82LP28-65 and 82LP2867 are thin ash beds. Sample 82LP28-99 is from directly beneath fallout pumice at the base of the Chaos Crags pyroclastic-flow section. The ash bed above 82LP28-59 is probably Mazama Ash. The other two ashes do not correlate with any known eruption from the Lassen area, and their sources are unknown. Samples 82LP28-40 and 82LP28-99 are roughly equivalent to W2231 and W-2232 respectively, for which ages of 5,400 \pm 600 and 4,600 \pm 600 years on bulk samples were reported by Crandell and others (1974). Sample 82LP28-99 provides a maximum age for the Chaos Crags eruptive sequence.

\section{USGS $1610 \quad$ 82LP29-150 2,635 \pm 58}

Charcoal from soil developed on till beneath Chaos Crags pyroclastic flows exposed in the south wall of Manzanita Creek (Manzanita Lake 7 1/2' quadrangle, $40^{\circ} 31.82^{\prime} 121^{\circ} 33.08^{\prime}$ ) near measured section 1 of Crandell and others (1974). Sample consists of disseminated bits of charcoal collected from lower B horizon of soil. Modern rootlets picked out by hand, and sample washed in water to remove adhering soil material. Sample dates soil formation and provides a maximum age for the Chaos Crags eruptive sequence. See samples USGS 1611 and 1612 from the same locality.

\section{USGS $1611 \quad$ 82LP29-312 $1840 \pm 58$}

Charcoal from soil developed on till beneath Chaos Crags pyroclastic flows exposed in the south wall of Manzanita Creek (Manzanita Lake 7-1/2' quadrangle, $40^{\circ} 31.82^{\prime} 121^{\circ} 33.08^{\prime}$ ) near measured section 1 of Crandell and others (1974). Sample consists of disseminated bits of charcoal collected from upper B horizon of soil. Modern rootlets picked out by hand, and sample washed in water to remove adhering soil material. Sample dates soil formation and provides a maximum age for the Chaos Crags eruptive sequence. See samples USGS 1610 and 1612 from the same locality.

USGS $1702 \quad$ 82LP32A $>42,500$

Sample collected from hornblende-biotite dacite pyroclastic flow widespread in the area around Manzanita Lake and Manzanita Creek (Manzanita Lake 7-1/2' quadrangle, 40 32.31' $121^{\circ} 34.93^{\prime}$. Unit dated by Crandell and others (1974) as $>32,000$ years and mapped by Christiansen and others (2002) as a pyroclastic flow related to emplacement of Eagle Peak (unit 
pfe). This pyroclastic flow is now known to be $66,000 \pm 4,000$ years old by ${ }^{40} \mathrm{Ar} /{ }^{39} \mathrm{Ar}$ dating (Christiansen and others, 2002). Sample consists of bits of charcoal picked from ash matrix about $15 \mathrm{~cm}$ below the top of the ash flow. Modern rootlets picked out by hand, and sample washed in water to remove adhering material. Sample provides a minimum age for a major silicic eruption that preceded emplacement of Lassen Peak and a control point for calibration of U-Th disequilibrium ages reported by Trimble and others (1984).

\section{USGS 1849 \\ LC83-402 \\ $31,280 \pm 202$}

Peat from section of glaciofluvial sediments exposed in the south bank of the West Fork of Hat Creek approximately $500 \mathrm{~m}$ east of the Devastated Area parking lot (West Prospect Peak $7-1 / 2^{\prime}$ quadrangle, $\left.40^{\circ} 30.80^{\prime} 121^{\circ} 27.62^{\prime}\right)$. Sample from the upper $1 \mathrm{~cm}$ of a discontinuous peat horizon in glaciofluvial sediments (unit fk, Christiansen and others, 2002) $1 \mathrm{~m}$ below fall and pyroclastic-flow deposits related to the rhyodacite of Kings Creek (unit pfk). Peat dried and modern rootlets removed by hand. Sample provides a maximum age for a major silicic eruption that preceded emplacement of Lassen Peak and a control point for calibration of U-Th disequilibrium ages reported by Trimble and others (1984). Calibrated age reported by Turrin and others (1998). Equivalent to sample USGS 2768.

\section{USGS 2050 \\ LC81-628 \\ $21,990 \pm 311$}

Sample from an active hot-spring deposit along the Hot Springs Creek Fault near Drakesbad (Reading Peak 7-1/2' quadrangle, 40 25.54' $121^{\circ} 24.03^{\prime}$ ). Sample consists of sinter and travertine with some lichen growing on it and probably contained some plant matter incorporated into the sinter. As much adhering organic material as possible scraped off. The results of this analysis cannot simply be interpreted as an age but indicate that a major component of $\mathrm{CO}_{2}$ in the Lassen geothermal system probably has been isolated from the atmosphere for 20,000 years or longer. Age calculated with measured $\delta^{13} \mathrm{C}=-4.22 \%$.

\section{$\begin{array}{llr}\text { USGS } 2061 & \text { 8-1-E } & 4,050 \pm 76\end{array}$}

Sample collected from stream cut in mudflow in the canyon of Mill Creek, south of Lassen Volcanic National Park (Lassen Peak 7-1/2' quadrangle, 40 24.99' $121^{\circ} 30.98^{\prime}$ ). Sample consists of fragments of charcoal picked from matrix at the base of a $>8$-m-thick mudflow. Modern rootlets picked out by hand, and sample washed in water to remove adhering soil material. Sample collected by Donna Marron and Julie Laudon; a preliminary age of $3860 \pm$ 50 years from it was reported in Marron and Laudon (1986). Sample dates mudflow or landslide activity from the hydrotherally altered core of Brokeoff Volcano into the canyon of Mill Creek. Probably dates the same deposit as USGS 2063, and may date the same deposit as USGS 830.

\section{USGS $2063 \quad$ 8-2-F-2 3,940 \pm 58}

Sample collected from stream cut in mudflow in the canyon of Mill Creek, south of Lassen Volcanic National Park (Lassen Peak 7-1/2' quadrangle, 40 24.66 $121^{\circ} 30.63^{\prime}$ ). Sample consists of fragments of wood from an organic-rich layer at the base of a $>8$-m-thick mudflow. Modern rootlets picked out by hand, and sample washed in water to remove adhering soil material. Sample collected by Donna Marron and Julie Laudon; a preliminary age of $3860 \pm$ 50 years from it was reported in Marron and Laudon (1986). Sample dates mudflow or landslide activity from the hydrotherally altered core of Brokeoff Volcano into the canyon of Mill Creek. Probably dates the same deposit as USGS 2061, and may date the same deposit as USGS 830. 
Sample collected from canyon exposure in upper Lost Creek, Devastated Area, Lassen Peak (West Prospect Peak 7-1/2' quadrangle, 40 30.07' $121^{\circ} 28.82^{\prime}$ ). Sample consists of charcoal picked from soil zone developed on dome-collapse pyroclastic flow from Lassen Peak dated at $27.1 \mathrm{ka} \mathrm{by}{ }^{40} \mathrm{Ar} /{ }^{39} \mathrm{Ar}$ (Turrin and others, 1998). Sample underlies debris-flow deposits consisting primarily of pinkish dacite of Lassen Peak (unit whe, Christiansen and others, 2002). Modern rootlets picked out by hand, and sample washed in water to remove adhering soil material. Sample provides a maximum age for the debris flows from Lassen Peak. Together with USGS 1352, sample brackets the age of unit whe between 7,550 \pm 55 and 8,130 \pm 110 years.

USGS 2494

LC86-1011D

$34,380 \pm 262$

Sample collected from National Park Service borrow pit near Sunflower Flat (Manzanita Lake $7-1 / 2^{\prime}$ quadrangle, $40^{\circ} 33.55^{\prime} 121^{\circ} 31.93^{\prime}$ ). Sample consists of a lump of charcoal from near the base of near-vent pumice-fall deposit underlying the Sunflower Flat pyroclastic flow (unit psf, Christiansen and others, 2002); about $4.5 \mathrm{~m}$ below Chaos Crags ash deposits. Modern rootlets picked out by hand. Sample dates the initiation of the eruptive sequence that emplaced the Sunflower Flat group of domes.

\section{USGS 2768 \\ LC89-1517 \\ $31,700 \pm 401$}

Peat from section of glaciofluvial sediments exposed in the south wall of the West Fork of Hat Creek approximately 500 m east of the Devastated Area parking lot (West Prospect Peak $7-1 / 2^{\prime}$ quadrangle, $\left.40^{\circ} 30.80^{\prime} 121^{\circ} 27.62^{\prime}\right)$. Sample from the upper $1 \mathrm{~cm}$ of a discontinuous peat horizon in glaciofluvial sediments (unit fk, Christiansen and others 2002) $1 \mathrm{~m}$ below fall and pyroclastic-flow deposits related to the rhyodacite of Kings Creek (unit pfk). Peat dried and modern rootlets picked out by hand. Sample provides a maximum age for a major silicic eruption that preceded emplacement of Lassen Peak. Calibrated age reported by Turrin and others (1998). Equivalent to sample USGS 1849.
USGS 3534
93CMS110
$7,260 \pm 58$

Sample collected from a coquina bed exposed in a trench dug in the 1910 s or early 1920 s for a tunnel outlet along the southeast shore of Eagle Lake (Gallatin Peak 7-1/2' quadrangle, 40 $36.82^{\prime} 120^{\circ} 43.57^{\prime}$ ). Sample consists mostly of freshwater snail shells but also contains sparse fish teeth and possibly ostracods. The coquina bed rests directly on the vesicular top of a subaerial basalt lava flow, which appears to be slightly eroded, probably by wave action along the shore of Eagle Lake. Sample collected by M.G. Sawlan. Sample places a minimum age on the formation of Eagle Lake and a maximum age of the underlying basalt flow. Age calculated with measured $\delta^{13} \mathrm{C}=1.12 \%$.

\section{Discussion}

\section{Cinder Cone}

Cinder Cone consists of a cinder cone, a mostly destroyed older cone remnant, a widespread fall deposit, and 5 lava flows in the northeastern corner of Lassen Volcanic National 
Park. The age and time span of activity at Cinder Cone has been controversial for over 100 years. Early workers interpreted it as erupting in the year 1851 (e.g. Finch, 1937). However, a variety of stratigraphic and geologic evidence summarized by Clynne and others (2000) indicates that all Cinder Cone deposits formed during a single, probably short-lived, eruptive episode. Ages reported here for samples dating the Cinder Cone eruption range from 440 to 140 years BP. Some of these are minimum ages, and others are maximum ages, as indicated in the sample descriptions. Those considered on geologic grounds to date the eruption of Cinder Cone most directly are the aspen tree buried by a lava flow (USGS 3684) and the two bark samples from beneath the ash layer (USGS 2615 and USGS 3683). The respective ages of these samples are $255 \pm 46,265 \pm 63$, and $270 \pm 42$ years BP. These three samples yield a weighted average of $264 \pm 28$ years BP, which is the preferred age for the Cinder Cone eruption (Table 1). Weighted averages calculated using all the samples with ages between 200 and 270 years are not significantly different from that calculated from the three best samples. Calibration of these ages to the radiocarbon timescale yields complex results that are not discussed here. The simplest interpretation of these results suggests that Cinder Cone erupted about 1650 A.D. (Clynne and others, 2000).

Table 1. Uncalibrated radiocarbon ages of Cinder Cone deposits.

\begin{tabular}{|c|c|c|c|}
\hline $\begin{array}{l}\text { Sample } \\
\text { number }\end{array}$ & Nature of sample & $\begin{array}{l}{ }^{14} \mathrm{C} \text { age } \\
\text { yrs BP }\end{array}$ & $\begin{array}{l}\text { Wt mean and std } \\
\text { error of the mean }\end{array}$ \\
\hline USGS 2769 & stump in ash & $140 \pm 42$ & \\
\hline USGS 3080 & $\log$ in Snag Lake & $200 \pm 50$ & \\
\hline USGS 2665 & tree buried by lava flow & $200 \pm 50$ & \\
\hline USGS 2493 & standing snag in ash & $250 \pm 46$ & \\
\hline USGS 3684 & aspen buried by lava flow & $255 \pm 46$ & \\
\hline USGS 2615 & tree bark under ash & $265 \pm 63$ & \\
\hline USGS 3683 & tree bark under ash & $270 \pm 42$ & \\
\hline USGS 3641 & $\log$ in Snag Lake & $270 \pm 42$ & \\
\hline USGS 2664 & charcoal from snag on lava flow & $405 \pm 42$ & \\
\hline USGS 2663 & wood from stump buried in lava & $430 \pm 50$ & \\
\hline USGS 2613 & wood from standing snag & $440 \pm 46$ & \\
\hline \multicolumn{2}{|c|}{3 best samples (USGS 3683, 2615, and 3684) } & & $264 \pm 28$ \\
\hline \multicolumn{2}{|c|}{5 samples between $250-270$ years } & & $262 \pm 21$ \\
\hline \multicolumn{2}{|c|}{7 samples between $200-270$ years } & & $246 \pm 18$ \\
\hline
\end{tabular}

\section{Chaos Crags}

The Chaos Crags comprise a group of six dacite lava domes associated with pyroclastic deposits in the northwestern corner of Lassen Volcanic National Park. The radiocarbon data are shown in Table 2 and the stratigraphy of the Chaos Crags is summarized in Table 3 . Numerous radiocarbon ages indicate that the explosive part of the sequence erupted within a short time. Three additional radiocarbon ages suggest the possibility that the dome sequence may have taken 800 years to be emplaced, but interpretation of the youngest dates is uncertain. 
The Chaos Crags eruption began with a vent-opening phase followed by explosive eruption and emplacement of the lower and middle pyroclastic flows in immediate succession. Extrusion of a small lava dome (dome A) and cooling of magma in the conduit then briefly plugged the vent. The weighted average age of 9 high-quality radiocarbon samples from the lower and middle pyroclastic flows is $1,118 \pm 17$ years BP. Reopening of the conduit, explosive disruption of dome A, and emplacement of the upper pyroclastic flow followed a possible short hiatus in the eruptive sequence (Muffler and others 1989). The weighted-average age of 7 highquality radiocarbon samples from the upper pyroclastic flow is $1,083 \pm 19$ years. The weightedaverage age of all 16 pyroclastic flow samples is $1,103 \pm 13$ years. Thus, the difference between the weighted-average ages of the upper pyroclastic flow and the middle and lower pyroclastic flows is small, and its interpretation is uncertain. Interpretation of these ages by calibration to calendar years is complicated by the complexity of the radiocarbon calibration curve in the range between 900 and $1000 \mathrm{AD}$.

Following eruption of the upper pyroclastic flow, domes B through F were emplaced. Later, dome $\mathrm{C}$ partially collapsed as a series of 3 cold rockfall avalanches that form the Chaos Jumbles. The radiocarbon age of the oldest of the avalanches is $278 \pm 30$ years BP (weighted average of 3 samples) comparable to the tree-ring ages of the oldest trees growing on the youngest avalanche (Heath 1959). Thus, the data confirm the interpretation of Crandell and others (1974) that all three rockfalls occurred in immediate succession.

Although the relative ages of domes $\mathrm{B}$ through $\mathrm{F}$ are more or less clear, the time interval over which they erupted is not. No radiocarbon or other dates relate directly to domes B, C or F. The composition and petrography of dome B more strongly resembles the upper pyroclastic flow than the other domes, suggesting that dome B is probably closer in age to the upper pyroclastic flow. Evidence concerning the time of emplacement of domes $\mathrm{C}$ through $\mathrm{F}$ however, is conflicting. Small hot collapse events from domes D and E emplaced short-runout lithic pyroclastic avalanches (Christiansen and others, 2002). A radiocarbon age of $430 \pm 30$ was obtained from charcoal beneath the pyroclastic avalanche deposit from domes $\mathrm{D}$, radiocarbon ages of $710 \pm 40$ and $230 \pm 40$ years were obtained from charcoal beneath the pyroclastic avalanche deposits from domes E. Dome D was reported to be steaming in the 1850s (Brewer, 1930), and the petrography and chemistry of the Chaos Crags magma changed subsequent to emplacement of dome B. Together these factors suggest that all the post-dome-B units could be significantly younger than the upper pyroclastic flow. However, the stratigraphic relationship of these radiocarbon samples to their associated avalanche deposit is equivocal. Numerous paleomagnetic directional data suggest that all the domes could have been emplaced within a few decades of the upper pyroclastic flow at about 1,100 years BP (D.E. Champion, written communication, 2002). Furthermore, the radiocarbon samples were collected from the thin edges of the avalanche deposits, where the material might have been colluvially reworked. The charcoal could represent young forest fires preserved with or beneath colluvium. 
Table 2. Uncalibrated radiocarbon ages of Chaos Crags deposits.

\begin{tabular}{|c|c|c|c|}
\hline Sample & Deposit & $\begin{array}{l}{ }^{14} \mathrm{C} \text { age } \\
\text { (yrs B.P.) }\end{array}$ & $\begin{array}{l}\text { Wt mean and std } \\
\text { error of the mean }\end{array}$ \\
\hline USGS 1847 & Chaos Jumbles & $265 \pm 42$ & \\
\hline USGS 1353 & Chaos Jumbles & $275 \pm 63$ & \\
\hline USGS 1848 & Chaos Jumbles & $305 \pm 58$ & \\
\hline WW 3849 & hot dome collapse avalanche E & $230 \pm 40$ & \\
\hline WW 3547 & hot dome collapse avalanche E & $730 \pm 40$ & \\
\hline WW 3287 & hot dome collapse avalanche D & $430 \pm 30$ & \\
\hline USGS 2344 & upper pyroclastic flow & $1,015 \pm 42$ & \\
\hline USGS 2343 & upper pyroclastic flow & $1,045 \pm 42$ & \\
\hline USGS 1616 & upper pyroclastic flow & $1,090 \pm 54$ & \\
\hline USGS 2346 & upper pyroclastic flow & $1,100 \pm 42$ & \\
\hline USGS 1351 & upper pyroclastic flow & $1,100 \pm 67$ & \\
\hline USGS 1606 & upper pyroclastic flow & $1,105 \pm 58$ & \\
\hline USGS 1608A & upper pyroclastic flow & $1,250 \pm 67$ & \\
\hline USGS 1607 & $\begin{array}{l}\text { upper pyroclastic flow } \\
\text { (reworked) }\end{array}$ & $1,480 \pm 58$ & \\
\hline USGS 2047 & middle pyroclastic flow & $1,005 \pm 58$ & \\
\hline USGS 1609B & middle pyroclastic flow & $1,035 \pm 54$ & \\
\hline WW 3286 & middle pyroclastic flow & $1,170 \pm 40$ & \\
\hline USGS 2345 & lower pyroclastic flow & $1,130 \pm 42$ & \\
\hline USGS 1612 & lower pyroclastic flow & $1,065 \pm 58$ & \\
\hline USGS 1609A & lower pyroclastic flow & $1,125 \pm 54$ & \\
\hline USGS 2049 & lower pyroclastic flow & $1,065 \pm 58$ & \\
\hline USGS 1614 & lower pyroclastic flow & $1,175 \pm 54$ & \\
\hline \multirow[t]{5}{*}{ USGS 2347} & lower pyroclastic flow & $1,175 \pm 42$ & \\
\hline & \multirow{3}{*}{\multicolumn{2}{|c|}{$\begin{array}{l}\text { Chaos Jumbles }(n=3) \\
\text { upper pyroclastic flow ( } n=7 \text {, all except USGS 1607) } \\
\text { middle and lower pyroclastic flows }(n=9)\end{array}$}} & $278 \pm 30$ \\
\hline & & & $1,083 \pm 19$ \\
\hline & & & $1,118 \pm 17$ \\
\hline & \multicolumn{2}{|c|}{ all pyroclastic flows $(\mathrm{n}=16$, all except USGS 1607) } & $1,103 \pm 13$ \\
\hline
\end{tabular}


Table 3. Stratigraphy of Chaos Crags after Muffler and others (1989) and Christiansen and others (2002) with average uncalibrated radiocarbon ages.

\begin{tabular}{|c|c|}
\hline Event & uncalibrated ${ }^{14} \mathrm{C}$ age (yrs B.P.) \\
\hline $\begin{array}{l}\text { Chaos Jumbles- } 3 \text { cold rockfall avalanches } \\
\text { Hiatus (?) }\end{array}$ & $278 \pm 28$ B.P. $(3)^{1}$ \\
\hline Dome F & \\
\hline Hot dome collapse avalanche from dome $\mathrm{E}$ & $\begin{array}{l}730 \pm 40 \text { B.P. }{ }^{2} \\
230 \pm 40 \text { B.P. }{ }^{2}\end{array}$ \\
\hline Dome E & \\
\hline $\begin{array}{l}\text { Hot dome collapse avalanche from dome D } \\
\text { Dome D }\end{array}$ & $430 \pm 42 \mathrm{BP}^{2}$ \\
\hline $\begin{array}{l}\text { Dome C (and unnamed dome remnant approximately same } \\
\text { age) }\end{array}$ & \\
\hline Hiatus? & \\
\hline Dome B & \\
\hline $\begin{array}{l}\text { Younger pumice cone and upper pyroclastic flow } \\
\text { Dome A (disrupted by eruption of upper pyroclastic flow) }\end{array}$ & $1,083 \pm 19$ B.P. (7) ${ }^{1}$ \\
\hline $\begin{array}{l}\text { Lower and middle pyroclastic flows } \\
\text { Older pumice cone (mostly buried) }\end{array}$ & $1,118 \pm 17$ B.P. $(9)^{1}$ \\
\hline
\end{tabular}

${ }^{1}$ The number in parentheses is the number of radiocarbon dates in the weighted average; weighted average of all 16 ages of pyroclastic flows is 1,103 $\pm 13 \mathrm{BP}$.

${ }^{2}$ Significance of these radiocarbon ages is uncertain; see text.

\section{References Cited}

Brewer, William H., 1930, Up and Down California in 1860-1865: Yale University Press, New Haven.

Chistiansen, R.L., Clynne, M.A., and Muffler, L.J.P., 2002, Geologic map of the Lassen Peak, Chaos Crags and Hat Creek area: U.S. Geological Survey Miscellaneous Investigations Map I-2723, in press.

Clynne, M. A., Champion, D.E., Trimble, D.A., Hendley, J.W. II, and Stauffer, P.H., 2000, How Old is "Cinder Cone"?--Solving a Mystery in Lassen Volcanic National Park, California: U.S. Geological Survey Fact Sheet 023-00, 4 p.

Crandell, D. R. and Mullineaux, D.R., 1970, Potential Geologic Hazards in Lassen Volcanic National Park, California: U.S. Geological Survey Administrative Report prepared for the National Park Service, $54 \mathrm{p}$.

Crandell, D. R., Mullineaux, D.R., Sigafoss, R.S., and Rubin, M., 1974, Chaos Crags eruptions and rockfall-avalanches, Lassen Volcanic National Park, California: U.S. Geological Survey Journal of Research v. 2, p. 49-59.

Diller, J.S., 1891, A late volcanic eruption in northern California and its peculiar lava: U.S. Geological Survey Bulletin 79, 33 p.

Finch, R.H., 1937, A tree ring calendar for dating volcanic events at Cinder Cone, California: American Journal of Science v. 33, p. 140-146. 
Heath, J.P., 1959, Dating Chaos Jumbles, an avalanche deposit in Lassen Volcanic Park: American Journal of Science v. 257, p. 537-538.

Heiken, G., 1978, Characteristics of tephra from Cinder Cone, Lassen Volcanic National Park, California: Bulletin of Volcanology v. 41. p. 119-131.

Marron, D.C. and Laudon, J.A., 1986, Susceptibility to mudflows in the vicinity of Lassen Peak, California, in Selected Papers in the Hydrologic Science: U.S. Geological Survey Water Supply Paper 2310, p. 97-106.

McGeehin, J., Burr, G.S., Jull, A.J.T., Reines, D., Gosse, J., Davis, P.T., Muhs, D,. and Southon, J.R., 2001, Stepped-Combustion 14C Dating of Sediment: A comparison with Established Techniques: Proceedings of the 17th International Radiocarbon Conference, Judean Hills, Israel, June 18-23, 2000, Radiocarbon v. 43-2A, Part 1, pp. 255-262.

Muffler, L.J.P., Bacon, C.R., Christiansen, R.L., Clynne, M.A., Donnelly-Nolan, J.M., Miller, C.D., Sherrod, D.R., and Smith, J.G., 1989, South Cascades arc volcanism, California and southern Oregon, in Chapin, C.E. and Zidek, J., eds., Field excursions to volcanic terranes in the western United States, Volume II. Cascades and Intermontane West: New Mexico Bureau of Mines and Mineral Resources, Memoir 47, p. 183-225.

Roberts, M. L., Bench, G.S., Brown, T.A., Caffee, M.W., Finkel, R.C., Freeman, S.P.H.T., Hainsworth, L.J., Kashgarian, M., McAninch, J.E., Proctor, I.D., Southon, J.R., and Vogel, J.S., 1997, The LLNL AMS Facility, in Jull, A.J.T., Beck, J.W., and Burr, G.S., eds., Proceedings of the Seventh International Conference on Accelerator Mass Spectrometry, Tucson, AZ, USA, May 20-24, 1996: North-Holland Press, pp. 57-61.

Robinson, S.W., 1977, US Geological Survey, Menlo Park, California, Radiocarbon measurements I: Radiocarbon v. 19, p. 460-464.

Robinson, S.W. and Trimble, D.A., 1981, US Geological Survey, Menlo Park, California, Radiocarbon measurements II: Radiocarbon v. 23, p. 305-321.

Trimble, D.A., Clynne, M.A., and Robinson, S.W., 1984, The application of uranium-thorium systematics to rocks from the Lassen dome field, California: U.S. Geological Survey Open-File Report 84-371, 99p.

Turrin, B.D., Christiansen, R.L., Clynne, M.A., Champion, D.E., Gerstel, W.J., Muffler, L.J.P., and Trimble, D.A., 1998, Age of Lassen Peak, California, and implications for the ages of late Pleistocene glaciations in the southern Cascade Range: Geological Society of America, Bulletin v. 110, p. 931-945. 